\title{
Phosphatidylinositol Glycan Anchor Biosynthesis Class U Protein
}

National Cancer Institute

\section{Source}

National Cancer Institute. Phosphatidylinositol Glycan Anchor Biosynthesis Class U

Protein. NCI Thesaurus. Code C39282.

Phosphatidylinositol glycan anchor biosynthesis class $U$ protein (435 aa, $50 \mathrm{kDa}$ ) is encoded by the human PIGU gene. This protein is involved in post-translational protein modification. 